\title{
Assessment and Empowerment of Poverty through Local Value in Mentawai Islands
}

\author{
Erwin $^{1}$, Isnarti Rika ${ }^{2}$, Putri Ardila ${ }^{3}$ \\ \{ Erwin_antro@yahoo.com ${ }^{1}$, rikaisnarti@soc.unand.ac.id², ardilaputris.ip@gmail.com ${ }^{3}$ \} \\ Anthropology Department, Universitas Andalas, Padang, Indonesia ${ }^{1}$, International Relations \\ Department, Universitas Andalas, Padang, Indonesia ${ }^{2}$, International Relations Department, Universitas \\ Andalas, Padang, Indonesia ${ }^{3}$
}

\begin{abstract}
This study analyses the premise, criteria and households size in Mentawai to determine the definition of poverty based on Mentawai's value. Further, it also analyses how small household's strategy to overcome poverty by utilizing household economic resources and distribution of work within the household. It uses an anthropology approach and qualitative methods; The research finds as follow; (a) The Mentawai society has its own criteria and measurement of poverty and poor households. They recognize two poor terminologies; Simagebak means poor; Simalilimai means to have nothing. Both of concepts are aimed at the migrant population that living in a single settlement or village location. (b) Institution-based kinship has a strategic role to empower and to solve the problem of poverty. The development of tribal-based local institutions can be seen in the context of a planned effort to develop human capacity, institutional capacity, improve and synchronize working relationships within institutions so that all administrators are encouraged to improve individual performance and institutional performance. (c) Mentawai communities have the social capital to address poverty, based on (i) Land as communal assets that have not been used and managed for productive enterprises. (ii) Strong social solidarity (mutual trust, help and mutual cooperation) at the family and community level, in gathering food and housing needs. Moreover, it has model empowerment through tribal-based local institutions to revitalize local agriculture (organic farming).
\end{abstract}

Keywords: Poverty, Local values, Empowerment model, Mentawai.

\section{Introduction}

West Sumatera is not the poorest province in Indonesia. However, poverty still exists in this province. In 2008 poverty rates in 19 districts in West Sumatra Province were 23,385. The number meant $22.07 \%$ of west Sumatran are among poor. In 2010, the index increased to 32,300 which mean $30 \%$ of the total population of West Sumatra are poor or around 4.7 million people [1]. The Mentawai Islands is the poorest district from 19 districts in West Sumatra Province. Whereas many as $80 \%$ of the population of Mentawai Islands Regency around 66,240 people still live in poverty from a total of 82,332 people.[2]

However, we cannot use the national index in Mentawai to measure poverty. In Mentawai, it is difficult to distinguish between poor, almost poor and non-poor households. Based on statistics data released by the central bureau of statistics in 2017 that collecting data using 14 
indicators of poor households stated that as many as $80 \%$ of the Mentawai residents around 82,332 people, which is about 66,240 people living in poverty [3]. The data show a high rate of poverty in the Mentawai community. The question is whether the poverty indicators used is by the characteristics of the Mentawai community. Most common indicators often do not capture the socio-cultural reality of various indigenous communities in Indonesia. The lifestyle of people in Indonesia is very diverse and multicultural. There are seven different forms of life patterns in Indonesia but living together can be a benchmark. Indonesian society consists of various ethnic groups and different backgrounds such as hunting gatherings, moving fields, raising fields on savanna, fishermen, rained agriculture, irrigation farming, service industries and more. In each pattern of life, it can be assumed that the criteria of poverty and welfare of life will certainly vary. Thus the size used should look at the concepts that exist in each culture of the community concerned [4].

The existence of diverse socio-cultural conditions in Indonesia requires the availability of poverty indicators that can accommodate socio-cultural variations. So that poverty reduction programs are more targeted. There are several indicators based on socio-cultural that can be used to indicate the poverty that is; ownership of agricultural land, ability to send children to school, ability to hold household gatherings, ability to provide food for daily consumption, level of difficulty in life, and ownership of livestock and certain housing conditions.

The Mentawai community is a socio-cultural group that is local and dispersed and lacks service of social, economic and politic. This community has a lifestyle and culture that is different from most community groups in Indonesia or west Sumatera. We cannot deny the fact that most of the people of Mentawai live in remote area and remoteness are one of the indicators to measure poverty based on economic and socio-cultural. However, when using this indicator in Mentawai, different perspective from the dominant community should be applied.

Central and regional government efforts to overcome the problem of poverty are seen in some policies. The presence of Law No. 32 of 2004 should be seen as momentum to realize decentralization of development and accelerate efforts to improve the welfare of the community. According to Mubyarto [5], anti-poverty policies or programs will succeed if the poor become the main actors in the fight against poverty. Furthermore, according to Mubyarto[6], to help the poor get out of the circle of poverty requires proper care, commitment, wisdom, organization, and programs.

In doing so, both government and civil society have created Mentawai Community Empowerment. It is a series of policies, strategies, programs and activities that are directed at efforts to provide authority and trust to local people to find problems and needs along with efforts to solve them based on their own strengths and abilities, through efforts to protect, strengthen, develop, consult and advocate for improvement level of social welfare[7]

The diversity of community ecosystem localities can reflect the differences and specificities of poverty faced by poor households and communities. Characteristics of poverty, in this case, relate to the size of poverty according to local (local) views and the nature of poverty itself (structural, natural or both). If two types of poverty are known, namely structural poverty and natural poverty, the differences in social systems (cultural structures and values) and rural types (natural) ecosystems have themselves pointed to differences in the factors that cause poverty [8].

Optimizing the allocation and pattern of distribution of resources in households and society can be seen as an effort to overcome poverty. Therefore, it is important to understand the concept of social energy, an internal force that exists in society. The concept of socio-cultural energy refers to three aspects, namely: (a) agreed basic ideas about a positive goal, (b) expectations (ideals) that are agreed to achieve the goal, and (c) togetherness (friendship) to achieve goals. 
Social energy is found in units of locality in the form of institutions that are oriented towards mutual welfare. Social Capital emphasizes the potential of groups and patterns of relationships between individuals in a group and between groups, which includes social networks, systems of norms and value systems that govern relationships between individuals and individuals with groups and groups with groups [9].

This study aims to understand the problem of poverty from the cultural dimension and the state of locality of the Mentawai people. This study aims to: first, analyze indicators and criteria for poor households in the community's view. Second, analyze the strategies of poor households in utilizing economic resources and the allocation of labor. Third, analyze the profile of development programs implemented by the government and non-governmental organizations. Foutrth, analyzing creative social energy that includes a system of values, norms, institutions and leadership that can be used as social capital and innovative potential to realize shared prosperity, both at the level of kinship units and units of locality.

\section{Methodology}

This study uses an anthropological approach to get an idea of how people think and behave — this research located in Sipora Island, Sioban Village, and Siberut Island Matotonan Village. Data collection techniques that used are: observation, interviews and focus group discussions (FGD). In each research location, in-depth interviews were conducted with ten key informants consisting of formal leaders; the village head, the village secretary, the head of the village consultative body and the hamlet head. In-Depth interviews with 30 household heads (husband and wife) were also conducted. FGDs were conducted in all location, the participants consisted of formal and informal leaders and heads of households, in each village there were 18 men and women. The variety of residents in FGD is very important. Therefore, the understanding of the subject needs to be discovered deeply. The data is collected from various sources. Data consist of information about poverty levels and development programs implemented in the people of Mentawai on Siberut Island.

Then, data is classified according to its character to describe the profile of poor households and local institutions that play a role in the community. The data is analyzed using interpretive understanding, mainly related to the existence of social capital, including the system of values, norms, institutions and leadership which constitute social capital at the level of kinship and locality. Finally, the conclusion focusing on indicators of poor households and local institutions that are most expected to play a role in overcoming poverty.

\section{Discussion and Results}

\subsection{Socio-Economic Conditions}

The economic system of the Mentawai people is still at the level of subsistence economy. The main livelihood of the people is hunting, gathering forest products and farming. The technology is used to process natural resources and to meet other living needs is made as simple as possible. There, economic activities carried out are closely related to the patrilineal kinship system. Every day, the patrilineal family functions as a production and consumption unit which divided based on sex. Various efforts are carried out by the family of the matrilineal area so that the needs of all matrilineal family members can survive as a unit of production and consumption. 
Every patrilineal family will have a big house called Uma. Uma is a residence of a patrilineal family, functioning among others; the place where various traditional ceremonies take place.

The staple food sources of the Mentawai people are sago, taro and banana. Meanwhile, protein food sources are pork, chicken, fish, and shell that available in high numbers. Each patrilineal family has a plant or tree: A palm plant, for its sago; coconut tree; banana tree; the taro and durian gardens and other plants. They also have stock raising such as pigs, chickens and some patrilineal families began to raise cattle

The main livelihoods of the community are gardening and farming with the main crops are Sago (palm), Banana, Keladi, Coconut and some of the market-oriented crops such as chocolate, areca nut, clove, and patchouli. Farming areas are outside the residential area to the middle of the forest. Besides farming, the people of Mentawai also have other livelihoods, namely raising and catching fish. The people also sell chocolate, areca nut, manau and rattan. They can reach range Rp. 100,000 to Rp. 400,000 in one month from its selling. Activities in this field are carried out by men and women. In the farm field, the work between men and women is almost the same. The difference lies only when new land is cleared, and land clearing is usually carried out by men. Women besides cooking for their household and working in the taro and banana plantations, also help work in the farm fields.

\subsection{Mentawai' Local Communities Criteria About Poverty}

Parsudi Suparlan [10], defines poverty as a low standard of living, namely the existence of a degree of lack of material in a number or a group of people compared to the standard of living that is generally applicable in society. Bureau of Statistics defines poverty in two ways, namely measures of income and non-income measures. The income measure looks at poverty from the level of individual income/expenditure to meet the minimum consumption / basic needs of the community. The minimum fulfillment requirement limit refers to; food produces 2100 kilos of energy per person every day. As for other measures, it is seen from the low access of the public to basic services such as 1) housing; 2) education; 3) health services; 4) sanitation facilities and clean water services; and 5) limitations on access to funding and business capacity, and others.

The terminology of poor which is known by the Mentawai people is in two terms; first, the term of poor it self-called Simagebak, second the person who is poor is called Simalilimai. Both concepts refer to immigrant residents (both for residents who come from the Mentawai tribe or other ethnic groups; Minangkabau, Javanese, Batak, and others) who live in one residential area or village. Usually, migrants do not own land, gardens or fields and do not have livestock. Land used by immigrants to build houses, gardening, and farming, Lands that belong to other tribes are obtained by following the customary provisions in Mentawai people.

According to community figure informants, the meaning of the word poor as a term is addressed to households whose conditions are as follows: 1). A family that only has one area of Sago gardens, taro gardens, and banana gardens. 2). Do not have pigs. 3). Do not have a house in the village, only have a hut in the garden. 4). having land that as a garden but the land belongs to other tribes. Moreover, according to tribe leaders, the criteria for poor households are households whose tribes have limited communal land so that households within the tribe only have a banana, taro and sago trees which amount only meet the household food needs of the tribe. They do not have fields planted with old plants, such as coconut, durian, and other forest plants.

Data tracking through the focus of group discussion in Madobag Village and Matotonan Village on the criteria of poor households is as follows:

- Households that cannot afford rice, so they only consume rice at certain times.

- Households that do not own land, and live in huts near the garden or near the pigsty. 
- All villagers, except villagers who work as civil servants, village heads and village officials.

- A household whose head of the family does not have a fixed income.

- Households that occupy houses that are damaged and cannot improve.

- Household where children only have basic education do not have the cost to continue their children education to a higher degree.

\subsection{The potential of Tribal-Based local Institutional}

The role of local institutions based on ethnicity or kinship is close within the community, not only regarding the ceremonial activities of life but also related to the fulfillment of economic needs of all patrilineal family members. Direct socio-economic assistance will be given to all patrilineal family members who need it, especially if there are sick, deceased and other family members. As for the fulfillment of food needs, all members of the tribe can cut down sago trees that grow on tribal land. That is, the needs of all tribal members to meet food needs are met in far more than enough, there is no starvation in the Mentawai people.

Development of tribal-based local institutions can be seen in the context of a planned business to develop human resource capacity, institutional capacity, improvement the synchronization of work relationships in institutions so that all administrators are encouraged to improve individual performance and institutional performance. There are several views about institutions as organizations and institutions as institutions. There are four ways to differentiate them: 1) that institutions tend to be traditional while organizations tend to be modern, 2) institutions come from the community itself while organizations come from above, 3) institutions and organizations are in a continuum where organizations are institutions that have not institutionalized and 4) organization is part of the institution.

Institutions focus on five things: 1) with regard to social aspects, 2) relating to abstract things that determine individual behavior in the social system, 3) relating to behavior or a set of behaviors or a way of acting that is good and for a long time in people's lives, 4) emphasis on behavior patterns that are approved and have sanctions in people's lives and 5) institutional implementation is directed at standard ways to solve problems that occur in certain social systems.

The potential of tribal-based local institutions in the Mentawai community is still possible if done seriously, considering there are some weaknesses and strengths. Tribal-based institutions in the Mentawai community on Siberut Island have several advantages, including: 1) in several tribes in the Madobag Village and Matotonan Village, there are already human resources at the tribal level who complete education at the undergraduate level; 2) existing human resources at the tribal level who have experience working in non-governmental organizations at the local and regional levels; 3 ) The tribe has assets in the form of land in sufficient amounts, but has not been utilized; 4) social solidarity is still strong at the ethnic level and is a source of social energy to be developed; 5) in the context of the development of cultural tourism, the role of tribal leaders in ceremonies at the same time as life is very important, and the position of Uma (a traditional house that is used as a place to live with all tribesmen) is still the center of the socioeconomic orientation of the people in the tribe.

Tribal-based institutional development is also closely related to the human resources owned by each tribe. Tribal institutions play a role in the lives of the Mentawai people, especially about decision making at various levels; at the level of tribal groups; community level and group collaboration with supra village organizations [11]

There are some weaknesses of tribal-based local institutions, so various methods are needed, including; 
- Assist and facilitate group management in compiling households' budget.

- Development of human resource capacity through training and technical guidance, and administrative and financial arrangements institutional.

- Strengthening institutional capacity to formulate work plans and open a network and connect it with supra-institutional villages, both government, private and national and international NGOs

- Using participatory methods and utilizing resources local to collect community participation.

Through these activities, it is expected that tribal-based local institutions will have the ability to: 1) Management of natural resources based on local agriculture (organic farming), forest management outside the National Park area. 2) Management of community-based cultural tourism.

\subsection{Social Capital in Mentawai Society}

The existence of social capital in the community determines whether a society will realize its prosperity sooner or later. On Siberut Island, the existence of social capital in the community is high, although the level of community welfare is still low compared to the general Indonesian community. It is closely related to the measure of welfare, which is relatively different between one ethnic group and another in Indonesia. Some opinions say the high or low social capital owned by a community is directly proportional to the quality of human development in each community is refuted or not applicable to the Mentawai people on Siberut Island.

To measure the social capital in the Mentawai community on the high Siberut Island, some parameters are used, including (a) the ability in the community to solve various problems in life together; (b) mutual awareness that there are many ways that each member of the community can do to improve their fate together, (c) cooperation to improve the quality of life; (d) the continued maintenance of mutual trust among fellow citizens will facilitate village and district governments to carry out various policies that are oriented to the welfare and advance of their people.

Communities that have high social capital will open up the possibility of resolving the complexity of the problem more easily because they build social relations of mutual trust. The principle of harmony and harmony with fellow human beings and with the environmental system is the basis of how to think, how to behave and how to act from the Mentawai people. The system of values and norms that governs social interaction among humans and the interaction of humans with the physical environment in the Mentawai community is framed in the belief system and knowledge system and becomes part of the culture of the Mentawai people.

The development approach carried out in the Mentawai community, often ignores the system of values and norms that exist in society. In some cases, religious rituals performed by the community were banned and the ceremonial equipment used was destroyed. Development assumptions that place local culture as a barrier to development in many ways have given rise to apathetic attitudes and behavior, loss of identity, feeling inferior when interacting with other ethnic groups [12].

The pattern of social relations that exist in the Mentawai community on Siberut Island has characteristics and is a typical strategy of survival. Social relations with fellow human beings and with the physical environment built over the years by the Mentawai people on Siberut Island are full of meaning, which contains the values of local wisdom. For the Mentawai people on Siberut Island, the system of values and norms that surrounds social relations between fellow human beings and with the physical environment will form the collective social energy that they 
will use to overcome various problems in their society. The sense of trust (trust) grows across cultural boundaries, the potential of tribal-based local institutions can be used in the development of Mentawai in the future.

In some cases, it appears that destructive behavior arises from within the community, usually because the community loses trust in the government. The concept of social energy refers to three aspects, namely: (a) agreed basic ideas about a positive goal, (b) agreed expectations or aspirations about the realization of the goals to be achieved, and (c) togetherness to achieve that goal. Social energy is usually found in units of locality that are oriented for mutual welfare. Moreover, it can also be explored from leadership practices from figures in society that are recognized in real-factual terms, not only because of their ideal-normative position [13].

In every community there is institutional and leadership performance that can be managed into social capital and development instruments. Its performance can vary from one village to another on Siberut Island. The performance of formal institutions and leadership at the village level can be expected to be social energy while seeking revitalization and innovation of more adaptive post-traditional social energy development — organized and relatively wellestablished social energy performance, which is indicated by the existence of groups of collaboration between families, as well as territorial cooperation between neighbors and between hamlets. There is also social energy which is the result of the innovation of residents in new settlements, based on the proximity of the house or place of residence.

\section{Conclusion}

Empowering the poor can be done through the development of tribal-based local institutions. The institutional approach is a synergistic process, where stakeholders share roles and involve local institutions in planning, preparation, implementation, maintenance, monitoring and evaluation, which are based on understanding the needs, problems, economic potential and opportunities according to the characteristics of locality, socio-economic and cultural conditions of the local community.

Simagebak means poor and Simalilimai, meaning not having anything. Both concepts refer to migrants. Migrants do not own land, gardens or fields and do not have livestock. Availability of local food (sago, taro, and bananas) in more than enough quantities. That is, from the fulfillment of local food needs there are no poor households in the Mentawai community on Siberut Island.

Strengthening tribal-based local institutions will be carried out with; first, providing assistance and facilitating group administrators in preparing Ad and ART. Second, development of human resource capacity through training and technical guidance, and administrative arrangements and institutional finance. Third, strengthening institutional capacity develops work plans and opens networks and connects them with supra-village institutions, both government, private and national and international NGOs. Forth, using participatory methods and utilizing local resources to gather community participation. 


\section{References}

[1] Biro Pusat Statistik, 2010, Provinsi Sumatera Barat dalam Angka, Pemerintah Propinsi Sumatera Barat, Padang.

[2] Biro Pusat Statistik, 2013, Kabupaten Kepulauan Mentawai dalam Angka. Pemerintah Kabupaten Kepulauan Mentawai, Tua Pejat

[3] Biro Pusat Statistik, 2010, Provinsi Sumatera Barat dalam Angka, Pemerintah Propinsi Sumatera Barat, Padang.

[4] Rudito, Bambang, 2013, Bebeitei Uma, Kebangkitan orang Mentawai, Jakarta: ICSD, dan Gading

[5] Mubyarto, 1998. Reformasi Sistem Ekonomi: Dari Kapitalisme Menuju Ekonomi Kerakyatan. Aditya Media. Yogyakarta

[6] Mubyarto, 1998. Reformasi Sistem Ekonomi: Dari Kapitalisme Menuju Ekonomi Kerakyatan. Aditya Media. Yogyakarta

[7] RI Minister of Social Affairs Regulation, No. 9, Year 2012).

[8] Sitorus, M.T.F. et. al., 1991, Wanita dan Kemiskinan: Studi tentang Status Wanita dalam Rumahtangga Miskin. Laporan Hasil Penelitian. BOGOR: BPPS Depsos RI- PSP LP IPB - PSW UNAND

[9] Erwin, 2006. Tanah Komunal: Melemahnya Solidaritas Sosial Pada Masyarakat Pedesaan Minangkabau, Penerbit Universitas Andalas Pers, Padang.

[10] Suparlan, Parsudi, 1994, Kemiskinan di Perkotaan, Penerbit Yayasan Obor Indonesia, Jakarta.

[11] Erwin, 2007. Pembangunan Sosial pada Masyarakat Mentawai di Pulau Siberut, dalam Nursyirwan Effendi dan Lucky Zamzami., Antropologi dan Pembangunan di Masyarakat Lokal,Penerbit Laboratorium Antropologi Fisip Unand, Padang.

[12] Erwin, 2007. Pembangunan Sosial pada Masyarakat Mentawai di Pulau Siberut, dalam Nursyirwan Effendi dan Lucky Zamzami., Antropologi dan Pembangunan di Masyarakat Lokal,Penerbit Laboratorium Antropologi Fisip Unand, Padang.

[13] Erwin, 2006. Tanah Komunal: Melemahnya Solidaritas Sosial Pada Masyarakat Pedesaan Minangkabau, Penerbit Universitas Andalas Pers, Padang 